\title{
Intention for Adopting Management Accounting System: An Empirical Research of Exploration to Public Non-business Generating Agencies
}

\author{
Pham Quang Huy, Vu Kien Phuc
}

\begin{abstract}
This research was modeled to examine and validate the components and factors which affected the intention to adopt (ITA) management accounting system (MAS) among public non-income generating agencies (PNGA) in Vietnam. The study employed primary data from a survey of 436 accountants working in these entities. Quantitative analysis methods applied to test the hypothesis in the research included Cronbach's Alpha reliability analysis, Exploratory Factor Analysis (EFA), Confirmatory Factor Analysis (CFA), and Structural Equation Models (SEM). The main consequences demonstrated that perceived usefulness (PU), perceived ease of use (PEOU), perceived financial cost (PFC) played important roles in affecting ITA of MAS. In addition, multiple group analysis (MGA) of SEM was pointed to test the moderation effect of leadership on the relationship between $P U, P E O U, P F C$ and ITA. Despite some limitations, the findings of this research not only serve as a reference for PNGAs in case of applying MAS through better understanding about the motivation and barriers in MAS implementation but also for the providers in seeking an effective way to approach the basic need of potential customers.

Keywords: public non-income generating agency, public sector Management Accounting System, Technology Acceptance Model
\end{abstract}

\section{INTRODUCTION}

The MAS was argued to be the best method to help all organizations to match with the criteria which belongs to internal structure of organization and environment (Etemadi et al., 2009; Hoque, 2011) through providing constructive information for designing, handling, supervising and making in decision (Soobaroyen \& Poorundersing, 2008; Ismail \& Isa, 2011). In the meanwhile, well-designated and dedicated MAS is supposed to provide managers together with suitable information for setting the objectives of performance, representation assessment standards and feedback to enhance managerial performance (MP).

With regard to the benefits of MAS adoption and the differences in implementing modern management accounting methods and techniques between developed and developing countries due to diverse conditions in nation as well as organization (Etemadi et al., 2009; Helden \& Uddin, 2016), research on MAS has come a long way to account for

Revised Manuscript Received on October 25, 2019

* Correspondence Author

Pham Quang Huy *, School of Accounting, University of Economics Ho Chi Minh City, Vietnam. Email: pquanghuy@ueh.edu.vn

Vu Kien Phuc, Vinh Long College of Economics and Finance, Vinh Long Province, Vietnam. Email: vkphuc2017@gmail.com determinants of applying MAS among the entities (Chenhall \& Langfield-Smith, 1998; Al-Omiri \& Drury 2007; Halbouni, 2014; Leite et al., 2015; Anh, 2016). Upon each empirical examination, there was diversity of critical factors concluded to have important influence on the adoption depending on the context and the methods of research were applied. Surprisingly, most of studies into MAS have been focused on mainly private sector organizations so that they could not provide enough useful insight for the public sector, especially PNGA although MAS is supposed to be the suitable tool to adapt and implement the autonomy effectively in PNGAs. In addition, on October 25th 2017, the Vietnam Party Central Committees has released the 19 resolution-NQ/TW on renovating organization and administration system and improving performance of the PNGAs, asserted the role and importance of the PNGAs among other economic entities of national economy, therefore, renovation of their operation mechanism has become essential in the context of reducing state budget constrain (Nguyen, 2018).

In respond to the need for more studies on MAS among PNGAs, this research will provide some insight about construct of intention of MAS adoption. With the view that adoption can be regarded as the initial step for continued use to take place, the researchers expect the contribution of the study can reserve in several aspects. Firstly, the introduction of MAS is made to increase the better perception about the benefits of adoption MAS, especially in rapid technological changes and the request of autonomy among the PNGAs. It has long been implied that an addition in knowledge can guide to adjust in behavior (Fabrigar et al., 2006). In other words, the more intentions were based on full knowledge, the better the intention could be predicted. Following this rationale, knowledge about MAS should be substantial in interpreting choices of adoption among PNGAs. Secondly, with the aims to introduce a model based on new determinants in order to predict intention of MAS adoption, the research not only focuses on the attitudes of PNGAs in adoption a new system but also examines whether the relationships between the attitudes of PNGAs as well as their adoption intention of MAS changed under various degrees of leadership. Thirdly, apart from implications shedding light for future research, the implications of MAS adoption are presented based on use behaviors, values, and costing can

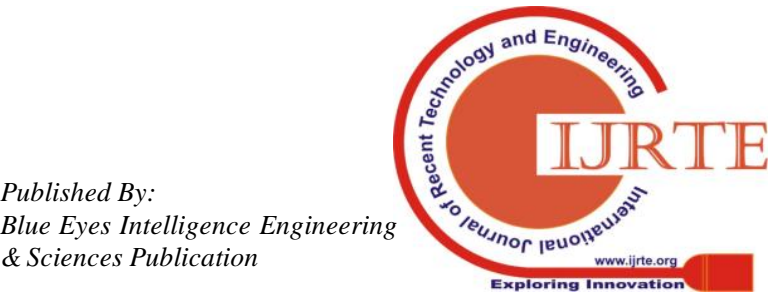


serve as a reference for PNGAs and for the providers in finding the effective methods to catch the attention of the potential customers.

The rest of this study is outlined as followings. Section 2 characterizes theoretical background, hypotheses, and the model of this research. Section 3 proposes methodology and experimental set up. The result is highlighted in Section 4. Based on these results, the researchers next draw to conclusions and implications to develop future research in last section.

\section{THEORETICAL BACKGROUND, HYPOTHESES, AND RESEARCH MODEL}

\section{A. Model of Extended TAM}

TAM, suggested by Davis (1989) and Davis et al. (1989) was conformed from the theory of reasoned action, has been widely applied by many scholars and practitioners to determine users' intentions towards the adoption of new technology. The model mentioned was originally formulated to model the implementation of information systems (IS) in the workplace (Bhattacherjee, 2001a, 2001b; Bhattacherjee \& Premkumar, 2004; Yang et al., 2012; Gao \& Bai, 2014a). The motive point of TAM was to confirm the impact of external variables on internal variables such as perspectives and intentions (Legris et al., 2003; Kwon \& Wen, 2010). The two particular beliefs were proposed in this model, PU and PEOU (Davis et al., 1989) had directly positive effects on measured usage (Wallace \& Sheetz, 2014).

\section{Perceived ease of use}

PEOU was considered as the key reliance in scheme of TAM and conceived as the level to which an individual trusts that employing a specific system could be graceful to use (Davis, 1989). Thus, the PNGAs are more likely to follow MAS if they are remarked it to be easy to run and do not concern too much hassle about managing. In other words, the easier to learn and use MAS, the more likely to be adopted by the organizations. Meanwhile, many past researches conducted over the last decade have proved the clear evidence regarding the critical effect of PEOU on intention, either directly or indirectly with its effect on PU (Davis et al., 1989; Agarwal \& Prasad, 1999; Venkatesh \& Morris, 2000; Yang, 2005; Yang et al., 2012). Hence, it is supposed that:

H1. PEOU has a significant positive impact on PU of adoption.

H2. PEOU has a significant positive impact on PNGAs' intentions to adopt MAS.

\section{Perceived usefulness}

Within the framework of TAM, users' ITA information technology was predicated largely on their PU of the system (Davis, 1989; Davis et al., 1989). In the circumstance of MAS, the users are going to adopt the system if they keep in view that the system will take benefits such as using MAS enable them to accomplish tasks more effectively; improve the organizations' performance and give the organization greater control over the work. On the contrary, users could refuse to utilize that system in case they also believe their job performance would be decreased through using it
(Buabeng-Andoh, 2018). Hence, in accordance with TAM, it is theorized that:

H3. PU has a significant positive impact on PNGAs' intentions to adopt MAS.

\section{Perceived financial cost}

According to previous empirical research, PU and PEOU were not the only beliefs that mediated the impact of the outside environment on thinking and ideas (Alsajjan \& Dennis, 2010). In respond to the limitation, many scholars have focalized on the expansion of TAM by including auxiliary variables to enhance its particularity, predictability and explanatory power (Davis et al., 1989; Chin \& Gopal, 1995; Karahanna \& Limayem, 2000; Legris et al., 2003; Venkatesh et al., 2003; Celik, 2008; Lee, 2009; Chong et al., 2010; Chiou \& Shen, 2012). Supposing this, with aims to ascertain what factors considerably affected the organization to adopt MAS, the additional construct was taken into the research structure was PFC. PFC is the extent to which the users believe that applying MAS would be costlier than other options. In other word, if MAS fails to deliver with suitable cost, then it has a negative effect on the TAM. Therefore, this study hypothesizes the following:

H4. PFC has a significant negative impact on PNGAs' intentions to adopt MAS.

\section{B. Management accounting systems}

It can be stated that, in unpredictable environments, the accomplishment to meaningful information leads to raise resource ration and increases the possibility of an improved positive results (Hammad et al., 2010). In other words, a conditional association presumed that useful information assists managers to make effective decisions and improves MP (Baines \& Langfield-Smith, 2003; Chenhall, 2003; Hammad et al., 2010). Well-designed and sophisticated MAS is likely to provide to managers with suitable information for getting performance objectives, performance assessment standards and response on performance leading to increase MP. MAS is known as complex thing when it produces data that is expend in scope, high timeliness, extreme aggregation and integration (Moores \& Yuen, 2001; Rasid et al., 2011).

As mentioned above, the characteristics of MAS applied in the research were based on the findings of Chenhall and Morris (1986) which included scope, timeliness, aggregation, and integration. According to Chenhall and Morris (1986), Scope which was relevant to the focus, quantification and time horizon of information, could limit or enlarge depending on whether the information coming from internal or external to companies, financial or non-financial, and past - or future-oriented. Timeliness refers to how immediately the information can be supplied upon request. While the categorization of information by time period or functional area was defined as aggregation, functional boundaries that assist coordinate various segments within a sub-unit was referred to integration characteristic of MAS. 
The rapid technological innovation has largely altered external environment of organizations and consecutively affected the internal processes same as MAS (Mat et al., 2010; Urquidi \& Ripoll, 2013). Information technology is comprised of information and communication technology equipment system, accounting software (Ismail \& King, 2007). The application of accounting software in accounting will release many advantages as accountants are just responsible for checking the legality and validity of accounting documents and analyzing the output information (Nguyen, 2010). Therefore, such advances in technologies like information technology (IT) together with computerization also lead the flows of information of management accounting (MAI) in entities be more integrated, promptly, exact and relevant (Granlund, 2011).

H5. MAS have positively affect PEOU of adoption.

With a view as an essential part of a company's information and control systems, a mass MAS (broad in extent, well-timed, integrated and aggregated) could offer essential information for managers to make decision to enhance performance of management (Mia \& Patiar, 2001; Hoque, 2011; Santos et al., 2012; McManus, 2013).

Furthermore, technology has supposed to have enormously influences on reach and aggregation of MAS through providing aggregated financial or non-financial information from different parts of the entities, information from inside or outside and related to historical or current events in a timely manner (Mia \& Winata, 2008; Zawawi \& Hoque, 2010; Granlund, 2011). Moreover, MAI in entities be more valuable, timely, accurate and relevant with the support of advances in technologies like IT and computerization (Granlund, 2011). For that reason, this system is always considered as an effective tool for the staff undertaking accounting work.

H6. MAS have positively affect PU of adoption.

Although the adoption of new systems could bring so many advantages to the entities, it still raises costs. The organizations have to organize equipment, technical facilities provide training program for accountants so that they may use the equipment proficiently and effectively and conduct the right to access and update information to ensure the confidentiality of accounting information. Moreover, security concerns, shortage of standards, regulations and so complex in the structure of the industry's network (Zhu et al., 2004) also increase cost if the adoption is approved.

H7. MAS have negatively affect PFC of adoption.

\section{Moderating effects of leadership}

With the highly regarded attribution in various organizations, the side of leadership is a requisite aspect for almost employers both in the public and private sector, especially in the era of globalization (Lee, 2000). Besides, the PNGAs' leaders are stipulated to be the responsible of organizing and guiding the implementation of accounting work followed the law on accounting (Law No 88, 2015). PNGAs' leaders are increasingly viewed as a key mechanism in the widespread efforts promoting autonomy for improvement. This released leaders out of boundary spanners, performing between organizations and the larger policy environment and transmitting their aligned (or misaligned) values, ideas, and rules. Considering these, PNGAs' leaders should take into account of aspects including strategic capabilities (SCs) and dynamic capabilities (DCs).

Strategic capabilities. SCs of organization may lie in its dimensions of resource, managing functions or its "networks of interdependence within the firm, between the firm and in its environment" (Lenz, 1980, p. 226). According to Simon et al (2015), a capability has to consist of three typical characteristics to hold strategic import despite organization's possession of numerous primary skills or capabilities to function efficiently including the value to the customer, the organization's capability to better than that of its competitors and a SCs being hard to emulate or replicate (Hubbard \& Beamish, 2011). The cost incurred when applying the new system consisted of the initial purchase price, equipment cost, and repair or updated charges. In general, the leader with higher SCs is more applicable to be the early adopters. They also manage to find financial resources to apply new system and put up with technologically disadvantageous factors to do with technology complexity, financial cost for adoption and to find out new experiences because the long-term benefits are their top concern. Therefore, this study hypothesizes:

H8a. SCs have positively moderate the effect of PEOU on intention to adopt MAS.

H8b. SCs have positively moderate the effect of PU on intention to adopt MAS.

H8c. SCs have negatively moderate the effect of PFC on intention to adopt MAS.

Dynamic capabilities. DCs are a set of specific and identifiable processes such as product growing, tactical conclusion making, and alliancing (Eisenhardt \& Martin, 2000). In this respect, leaders may tend to identify DCs through seeking appropriated ways of improving performance or just enabling these identified capabilities as well as managing any on-going tensions arising as a partial of reconfiguration procedure instead. DCs would regulate the effects of organization's perceptions of their adoption intention. The leaders with higher DCs were more likely to get a stronger intention to adopt MAS for the same grade of perceptions about the MAS. They are more likely to be involved in the new MAS and may tend to put up with the financial cost of applying current system, perceive the relative advantage of the new system, and extra adopt the recent as well as up-to-date system in collation to those with low DCs. Hence, this study hypothesizes:

H9a. DCs have positively moderate the effect of PEOU on intention to adopt MAS.

H9b. DCs have positively moderate the effect of PU on intention to adopt MAS.

H9c. DCs have negatively moderate the effect of PFC on intention to adopt MAS.

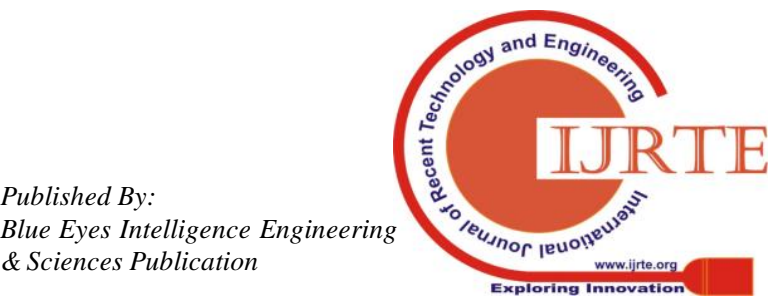




\section{The Model of Research}

To meet these objectives mention above, the model of research has established on the extended TAM with MAS, presented one leadership moderator leading to the intention of adopt MAS in Vinh Long PNGAs was outlined in Figure 1 .

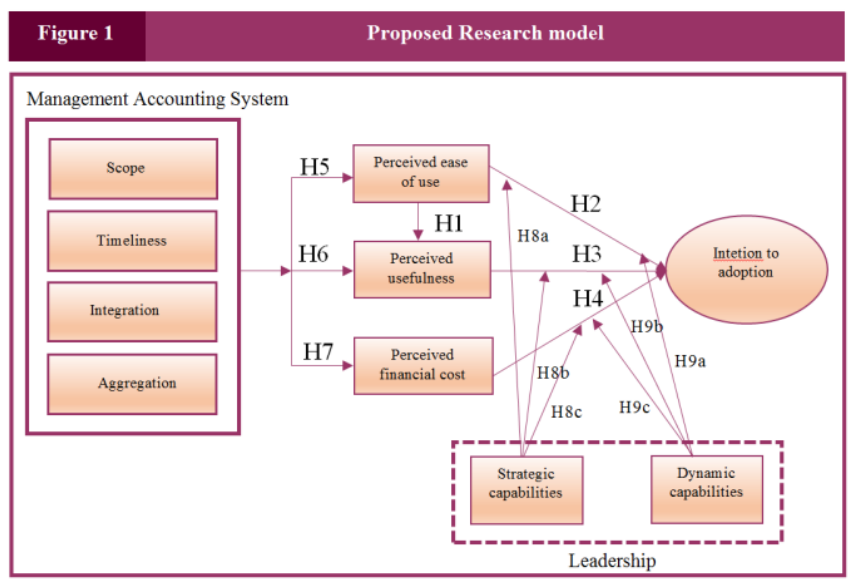

\section{SUGGESTED METHODOLOGY AND EXPERIMENTAL SET UP}

\section{Procedure}

The translation and back-translation process was used to develop a Vietnamese version of the scale. Besides, in order to make sure the validity and contribute to the amendment in the formation, design and layout of questionnaire, two experts with experience of applying MAS among Vinhlong PNGAs conducted the pilot test. They were requested not only to review the descriptive and the objective questions, provide their response but also to verify any ambiguity or misunderstanding information. As a result, the items and questions in the proposed questionnaire were adjusted; a structured table of questions was developed for gathering of ultimate data. These questionnaires contributed was lasted from December in 2018 to March in 2019 and personally collected by the researchers.

\section{Data collection}

Quota sampling procedure followed in the survey was based on the numbers of areas among Vinhlong PNGAs. Once the SEM technique had been applied for analytical procedures, it could concern diversified overall fit indices and the collection of the proper approach (Lei \& Wu, 2007). In this respect, a "critical sample size" of 200 was proposed by Sivo et al. (2006) and Hoelter (1983) to provide sufficient statistical power for data analysis. While according to Bollen (1989), with a minimum of 5 samples, there was an agreement among many scholars that the sample size must be ten to twenty times the number of observed variables (Hair, 2010; Kline, 2011; Harrell, 2015). Thus, the minimum sample size needed for this article is 410 for estimation the theoretical model containing forty one parameters. Finally, 436 complete responses were obtained due to the fact that some of these were erroneous and incomplete. There were some regions which could not reach the target number, but not significantly (i.e. Binhminh; Binhtan; Mangthit),

therefore, the survey sample was considered as a representative of the whole and the results of this sample are also the results focusing on the intention to adopt the MAS among Vinh Long PNGAs.

\section{Measurements of Variables}

In this research, constructs were measured using multiple items validated in prior literature and modified to fit the context of MAS adoption. The five-point Likert scale was used in this article as it was a psychometric scale that was used to catch the responses from the respondents and produce a reliable and valid outcome (Zikmund et al., 2010). Table 1 described a sample questionnaire comprising of all 41 attributes.

Independent variable. 6 items on Scope (Chenhall \& Morris, 1986; Cheng, 2012; Etemadi et al., 2009; Susanto, 2010; Chung et al., 2012); 4 items on Timeliness (Chenhall \& Morris, 1986; Agbejule, 2005; Etemadi et al., 2009; Susanto, 2010); 4 items on Integration (Chenhall \& Morris, 1986; Agbejule, 2005; Bouwens \& Abernethy, 2000); 6 items on Aggregation (Chenhall \& Morris, 1986; Bouwens \& Abernethy, 2000; Agbejule, 2005).

Dependent variable. 3 items on PEOU (Davis, 1989; Davis et al., 1989); 3 items on PU (Davis et al., 1989; Wu et al., 2007); 3 items on PFC (Luarn \& Lin, 2005; Sripalawat et al., 2011); 3 items on ITA (Davis et al., 1989; Davis, 1993).

Moderating variable. 3 items on SCs (Moffat \& Simon, 2011; Sarasvathy \& Dew, 2013); 5 items on DCs (von Krogh et al., 2001; Simon, 2010).

\begin{tabular}{|c|c|}
\hline Table & Measures and items \\
\hline $\begin{array}{c}\text { Constru } \\
\text { ct }\end{array}$ & Measurement items \\
\hline \multicolumn{2}{|l|}{ Scope } \\
\hline SCO1 & Information corresponds to possible future events \\
\hline SCO2 & Qualification of the likeliness of forthcoming events appears \\
\hline SCO3 & $\begin{array}{l}\text { Non-economic information including client preferences, } \\
\text { employee perspective are focused }\end{array}$ \\
\hline SCO4 & $\begin{array}{l}\text { Information associates with expanded factors outside to the } \\
\text { entity }\end{array}$ \\
\hline SCO5 & Non-financial information refers to the output \\
\hline SCO6 & Non-financial information relates to information of market \\
\hline \multicolumn{2}{|c|}{ Timeliness } \\
\hline TIME1 & Information that is offered instantly as requested \\
\hline TIME2 & Information that is purveyed automatically immediately \\
\hline TIME3 & $\begin{array}{l}\text { Reports which are supplied regularly on a systematic, frequent } \\
\text { basis }\end{array}$ \\
\hline TIME4 & $\begin{array}{l}\text { Relevant information is prepared in reports without delay right } \\
\text { after appearance of event }\end{array}$ \\
\hline \multicolumn{2}{|c|}{ Integration } \\
\hline INTE1 & $\begin{array}{l}\text { Information on actual goal of the activities of all departments } \\
\text { within organization }\end{array}$ \\
\hline INTE2 & $\begin{array}{l}\text { Information relates to the influence on different departments' } \\
\text { decisions on performance of organization }\end{array}$ \\
\hline INTE3 & $\begin{array}{l}\text { Cost and price information of the divisions were provided } \\
\text { suitably }\end{array}$ \\
\hline INTE4 & $\begin{array}{l}\text { Information on the effect of decisions at entity, and the impact of } \\
\text { other division' decisions on responsible area }\end{array}$ \\
\hline \multicolumn{2}{|c|}{ Aggregation } \\
\hline AGGR1 & $\begin{array}{l}\text { Information supplied in the different sections or functional areas } \\
\text { in organization }\end{array}$ \\
\hline AGGR2 & Information has affected on events on distinct periods \\
\hline & $\begin{array}{l}\text { Information has been prepared to indicate effect of events on } \\
\text { various functions }\end{array}$ \\
\hline
\end{tabular}




\begin{tabular}{|c|l|}
\hline AGGR4 & $\begin{array}{l}\text { Information on effect of different departments' activities on } \\
\text { summary reports }\end{array}$ \\
\hline AGGR5 & $\begin{array}{l}\text { Information has been formatted suitably for giving the input into } \\
\text { decision models }\end{array}$ \\
\hline AGGR6 & $\begin{array}{l}\text { Information in forms is able to do managers to conduct "what-if" } \\
\text { analysis }\end{array}$ \\
\hline Perceived ease of use \\
\hline PEOU1 & $\begin{array}{l}\text { Interacting with MAS does not request lots of entity cognitive } \\
\text { effort }\end{array}$ \\
\hline PEOU2 & $\begin{array}{l}\text { It could be easy for the organization to become skillful at using } \\
\text { MAS }\end{array}$ \\
\hline PEOU3 & MAS is considered to be easy to use \\
\hline Perceived usefulness \\
\hline PU1 & $\begin{array}{l}\text { Using MAS enable the responsible department to accomplish } \\
\text { tasks more effectively }\end{array}$ \\
\hline PU2 & Using MAS improves the organizations" performance \\
\hline PU3 & Using MAS gives the organization greater control over the work \\
\hline Perceived financial cost \\
\hline PFC1 & Using MAS is cost burden to the organization \\
\hline PFC2 & $\begin{array}{l}\text { The device setup to using MAS in the organization costs lot of } \\
\text { money }\end{array}$ \\
\hline PFC3 & The fee to update the software is expensive for the organization \\
\hline Intention to adopt \\
\hline ITU1 & Our organization intend to adopt MAS in the future \\
\hline ITU2 & Our organization predict to adopt MAS in the future \\
\hline ITU3 & Our organization plan to adopt MAS in the future \\
\hline Strategic capabilities \\
\hline STR1 & Good leaders and vision \\
\hline STR2 & Collection and retention of good employees \\
\hline STR3 & Adaptability/flexibility \\
\hline STR4 & Invention and creativity \\
\hline Dynamic capabilities \\
\hline DYN1 & Strategic thinking \\
\hline DYN2 & Flexible leadership \\
\hline DYN3 & Networks and alliances \\
\hline DYN4 & Knowledge management \\
\hline DYN5 & Technology flexibility \\
\hline & \\
\hline
\end{tabular}

\section{Statistical data analysis}

An initial screening of each scale was conducted using item-total correlations (Cronbach's Alpha) and EFA through using SPSS 25.0. CFA has been applied to evaluate the psychometric properties of the scales and test the discriminant validity of the measures and SEM was conducted through AMOS 22.0. Maximum likelihood (ML) estimation procedures were used because of these afford more security in samples which might not present multivariate normality (Muthen \& Kaplan, 1985). Besides, the MGA was performed in this research for testing the existence of the moderating effects on the model of research.

\section{RESULTS}

\section{A. Descriptive features of the usable respondents}

In the midst of the 436 usable respondents, 105 respondents $(24.08 \%)$ were males, as well as 331 respondents $(75.92 \%)$ were females. The rationing of age was as follows: from 20 to under $30(9.63 \%)$, from 30 to under $40(33.03 \%)$, from 40 to under 50 (44.72\%), 50-60 (12.29\%). Educational levels were generally high. Respondents who had completed junior college numbered 15.60 per cent while respondents who had graduated with bachelor level numbered 84.40 per cent of the sample of survey. Furthermore, the distribution of duration of experience (the respondents' experience in working as an accountant) was as followings: under 3 years (11.47 per cent), 3 to under 6 years ( 19.27 per cent), 6 to under 9 years

\section{(23.85 per cent), and over 9 years (45.41 per cent).}

\section{B. Results of structural modeling analysis}

\section{Analysis of the model of measurement}

The construct validity is the extent to which a set of measured variables actually indicates the theoretical latent build up those are designed to get the measurement (Hair et al., 2010, p. 631). Thus, CFA was applied to purify the model of measurement and to evaluate the convergent and discriminant validity. Cronbach's alpha was calculated to analyze the internal consistency of the construct and its reliability. There were 6 observed variables of the scales with Corrected Item-Total Correlation under 0.30 deleted, distributed this did not affect the meaning of the construct. Apart from factor loadings (standardized estimates), Average Variance Extracted (AVE) and Composite Reliability (CR) for each construct were utilized in its research to examine the reliability of all of the constructs (Nunnally, 1978; Hair et al., 1998; Byrne, 2001; Holmes-Smith, 2001). The final figures also presented in Table 2 demonstrated an acceptable level of reliability for all constructs.

\begin{tabular}{|c|c|c|c|c|c|c|}
\hline \multirow{3}{*}{$\begin{array}{c}\text { Table } 2 \\
\text { Variables }\end{array}$} & \multicolumn{6}{|c|}{ Reliability and convergent validity assessment } \\
\hline & \multirow[b]{2}{*}{ Item } & \multirow{2}{*}{$\begin{array}{c}\text { Indicator } \\
\text { Reliability } \\
\text { Factor } \\
\text { Loadings }\end{array}$} & \multirow{2}{*}{$\begin{array}{c}\text { Convergent } \\
\text { Validity } \\
\begin{array}{c}\text { Average Variance } \\
\text { Extracted (AVE) }\end{array}\end{array}$} & \multicolumn{2}{|c|}{ Construct Reliability } & \multirow{2}{*}{$\begin{array}{l}\text { Discriminan } \\
\text { validity }\end{array}$} \\
\hline & & & & $\begin{array}{l}\text { Cronbach's } \\
\text { Alpha (CA) }\end{array}$ & $\begin{array}{c}\text { Composite } \\
\text { Reliability (CR) }\end{array}$ & \\
\hline \multirow{5}{*}{ Scope } & scol & 0.755 & \multirow{5}{*}{0.511} & \multirow{5}{*}{0.839} & \multirow{5}{*}{0.839} & \multirow{5}{*}{ Yes } \\
\hline & $\mathrm{SCO} 2$ & 0.712 & & & & \\
\hline & SCO3 & 0.732 & & & & \\
\hline & SCO4 & 0.622 & & & & \\
\hline & SCO5 & 0.748 & & & & \\
\hline \multirow{3}{*}{ Timeliness } & TIME1 & 0.786 & \multirow{3}{*}{0.620} & \multirow{3}{*}{0.862} & \multirow{3}{*}{0.867} & \multirow{3}{*}{ Yes } \\
\hline & TIME2 2 & 0.706 & & & & \\
\hline & $\begin{array}{l}\text { TIME3 } \\
\text { TIME4 }\end{array}$ & $\begin{array}{l}0.848 \\
0.808\end{array}$ & & & & \\
\hline \multirow{3}{*}{ Integration } & INTE1 & 0.807 & \multirow{3}{*}{0.669} & \multirow{3}{*}{0.858} & \multirow{3}{*}{0.858} & \multirow{3}{*}{ Yes } \\
\hline & INTE2 & 0.791 & & & & \\
\hline & NTE4 & 0.859 & & & & \\
\hline \multirow{4}{*}{ Aggregation } & AGGR1 & 0.714 & \multirow{4}{*}{0.607} & \multirow{4}{*}{0.858} & \multirow{4}{*}{0.860} & \multirow{4}{*}{ Yes } \\
\hline & AGGR2 & 0.727 & & & & \\
\hline & AGGR3 & 0.839 & & & & \\
\hline & AGGR5 & 0.830 & & & & \\
\hline $\begin{array}{l}\text { Perceived } \\
\text { ease }\end{array}$ & PEOU1 & 0.770 & & & & Yes \\
\hline $\begin{array}{l}\begin{array}{l}\text { ease } \\
\text { of use }\end{array} \\
\text {. }\end{array}$ & $\begin{array}{l}\text { PEOU2 } \\
\text { PEOU3 }\end{array}$ & 0.821 & 0.019 & 0.829 & 0.830 & \\
\hline & PU1 & 0.813 & & & & Yes \\
\hline $\begin{array}{l}\text { Perceived } \\
\text { usefulness }\end{array}$ & PU2 & 0.815 & 0.690 & 0.869 & 0.870 & res \\
\hline & PU3 & 0.854 & & & & \\
\hline & PFCl & 0.732 & & & & \\
\hline financial cost & PFC2 & 0.773 & 0.570 & 0.798 & 0.799 & res \\
\hline & PFC3 & 0.749 & & & & \\
\hline & ITAI & 0.851 & & & & \\
\hline $\begin{array}{l}\text { Intention to } \\
\text { adoption }\end{array}$ & ITA2 & 0.740 & 0.580 & 0.803 & 0.805 & Yes \\
\hline & ITA3 & 0.684 & & & & \\
\hline & STRI & 3.53 & & & & \\
\hline Strategic & STR2 & 3.55 & 0603 & 0858 & 0858 & Yes \\
\hline capabilities & STR3 & 3.58 & & & & res \\
\hline & STR4 & 3.68 & & & & \\
\hline & DYN1 & 3.65 & & & & \\
\hline & DYN2 & 3.52 & & & & \\
\hline $\begin{array}{l}\text { Dynamic } \\
\text { capabilities }\end{array}$ & DYN3 & 3.63 & 0.619 & 0.889 & 0.890 & Yes \\
\hline & DYN4 & 3.55 & & & & \\
\hline & DYN5 & 3.65 & & & & \\
\hline
\end{tabular}

(Source: Researchers' Computation, 2019)

The procedure described by Fornell and Larcker (1981) was used to test for discriminant validity in this study. The AVE for all variables exceeded the proposed value of 0.50 signifying that the variance captured by the construct was significantly greater than that attributable to error. Moreover, AVE measures for all of the constructs were much larger than the square of correlation between them providing whole manifestation of discriminant validity (Fornell \& Larcker, 1981). Those figures were revealed on diagonal of Table 3. 


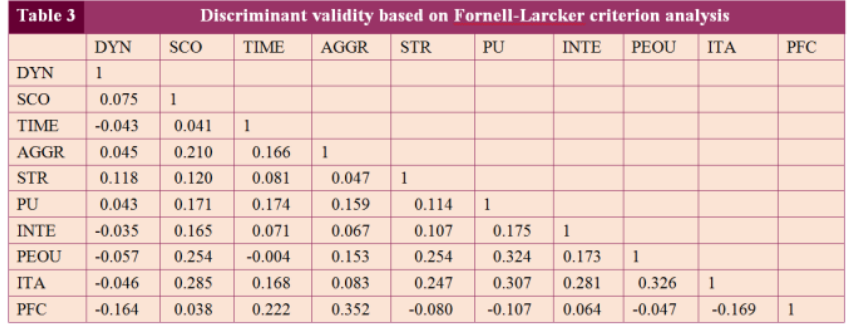

(Source: Researchers' Computation, 2019)

Third, the overall fit indices of measurement model were $\mathrm{df}=584, \chi 2 / \mathrm{df}=1.275, \mathrm{p}<0.001, \mathrm{GFI}=0.919, \mathrm{TLI}=0.975$, $\mathrm{CFI}=0.978$, and RMSEA $=0.025$. Thus, the results of CFA pointed to that the indices were over their respective general acceptance levels as stated by Bagozzi \& Yi (1988); Hair et al. (1998) and Byrne (2001).

\section{Analysis of structural model}

Structural model. The following point and step were to examine the structural model for the study, the overall fit indices for the structural model were $\mathrm{df}=339, \chi 2 / \mathrm{df}=1.489$, $\mathrm{p}<0.001$, GFI $=0.926$, TLI $=0.964$, CFI $=0.968$, and RMSEA $=0.034$. Based on the regulations of previous studies (Bagozzi \& Yi, 1988; Hair et al., 1998; Byrne, 2001), the data showed that the fit indices for this structural model were quite acceptable.

Hypothesis testing. Properties of the causal paths, including standardized path coefficients $(\beta)$ and p-values, were shown in Table 4 . The result proved that PEOU had respective influence on PU $(\beta=0.269 ; p<0.05)$, thus, H1 was confirmed. The effects of PU, PEOU, PFC on ITA were significant $(\beta=0.248,0.217,-0.116 ; p<0.05)$; hence, $\mathrm{H} 2-\mathrm{H} 4$ were supported. On the part of relationships between MAS and PEOU; PU; PFC, the effects of MAS on PFC were more significant than that of MAS on PEOU and PU with $\beta=$ 0.123 in comparison with $\beta=0.068$ and $\beta=0.048(p<0.05)$; hence, $\mathrm{H} 5-\mathrm{H} 7$ were verified.

\begin{tabular}{|c|c|c|c|c|c|c|c|c|}
\hline Table 4 & \multicolumn{8}{|c|}{ Hypothesis testing results } \\
\hline Relevant Hypothesis & \multicolumn{3}{|c|}{ Relevant path } & Estimate & S.E. & $C . R$. & $p$-value & Inference \\
\hline H1 & PEOU & $\Rightarrow$ & PU & 0.068 & 0.026 & 2.657 & 0.008 & Supported \\
\hline H2 & PEOU & $\Rightarrow$ & ITA & 0.048 & 0.022 & 2.145 & 0.032 & Supported \\
\hline H3 & $\mathrm{PU}$ & $\Rightarrow$ & ITA & 0.123 & 0.036 & 3.410 & 0.000 & Supported \\
\hline $\mathrm{H} 4$ & PFC & $\Rightarrow$ & ІтА & 0.269 & 0.057 & 4.740 & 0.000 & Supported \\
\hline H5 & MAS & $\Rightarrow$ & PEOU & 0.248 & 0.058 & 4.266 & 0.000 & Supported \\
\hline H6 & MAS & $\Rightarrow$ & PU & 0.217 & 0.059 & 3.713 & 0.000 & Supported \\
\hline H7 & MAS & $\Rightarrow$ & PFC & -0.116 & 0.050 & -2.305 & 0.021 & Supported \\
\hline
\end{tabular}

(Source: Researchers' Computation, 2019)

To evaluate the indirect effects, the bootstrapping bias-corrected confidence interval procedure was used to the mediation model (Preacher \& Hayes, 2008). The Bootstrapping technique was applied in this research with a whole of number of 1,500 random observations generated from the original sample and selected bias-corrected Bootstrapping method with 95 percent confidence intervals in the estimation of the suggested model. The estimation results show that the Bias and the standard deviation of the bias (SE-Bias) between bootstrapping estimation and the ML used in the verification appeared, but standard deviations of the bias was not statistically significant, proving that the estimated results in this study were reliable.

\section{Moderating effects of leadership}

Multiple group analysis. MGA could be used to test the reality of the moderating effects on the structural model by analyzing the signification of the differences between parameters considered by the structural model between the groups proposed (Singh, 1995; Byrne, 2001; Arbuckle, 2003).

Strategic capabilities. For the formation of the groups, the study has separated the sample of SCs into two altered groups (high SCs versus low SCs) in line with the sample median. The results of the test of the difference between the compatibility criteria between the Variance Measurement model $(\mathrm{VMm})$ and Partial Invariance Measurement model (PIMm) display that the difference between the two models is statistically significant $(p=0.000<0.05)$. Therefore, the $\mathrm{VMm}$ was selected to conclude the difference of factors in the research model between the two median groups. Table 5 showed that there were significant differences in the unstandardized coefficients of PEOU $(\beta=0.286 ; p<0.05)$, PU $(\beta=0.261, p<0.05)$, and PFC $(\beta=-0.107, \mathrm{p}<0.05)$ affecting ITA could be observed via the moderating effect of $\mathrm{SCs}$, thus H8a, H8b, and H8c were supported. Therefore, the relationship between PEOU and ITA and the relationship between PU and ITA were stronger among respondents with high level of SCs than among respondents with low level of SCs. Nonetheless, the relationship between PFC and ITA was weaker among respondents with high range of SCs than among respondents with low level of SCs.

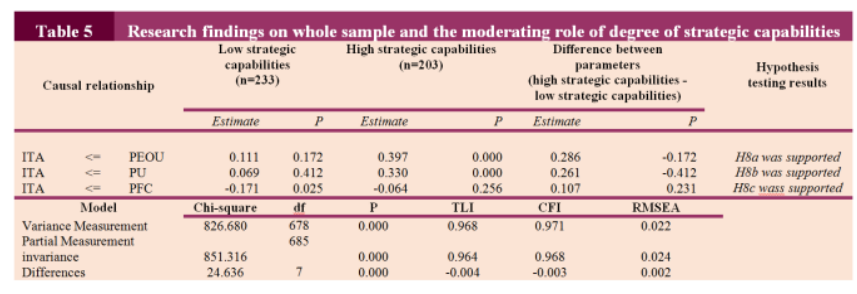

(Source: Researchers' Computation, 2019)

Dynamic capabilities. The researchers divided the sample of DCs into two different groups (high DCs versus low DCs) in accordance with the sample median. The results of the test of the difference between the compatibility criteria between the VMm and PIMm showed that the difference between the two models was statistically significant $(p=0.000<0.05)$. Therefore, the VMm was selected to conclude the difference of factors in the research model between the two median groups. It is not difficult to see in Table 6 , significant differences in the unstandardized coefficients of PEOU $(\beta=$ 0.374, $\mathrm{p}<0.05)$, PU $(\beta=0.167, \mathrm{p}<0.05)$, and PFC $(\beta=$ $0.122, \mathrm{p}<0.05$ ) affecting ITA could be observed via the moderating effect of DCs, thus $\mathrm{H} 9 \mathrm{a}, \mathrm{H} 9 \mathrm{~b}$, and $\mathrm{H} 9 \mathrm{c}$ were supported. Hence, the relationship between PEOU and ITA and the relationship between PU and ITA were stronger among respondents with high level of DCs than among respondents with low level of DCs. However, the relationship between PFC and ITA was weaker among respondents with high level of DCs than among respondents with low level of DCs. 


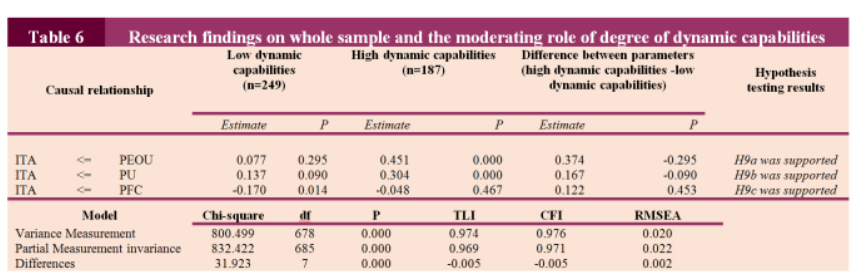

(Source: Researchers' Computation, 2019)

\section{DISCUSSION AND CONCLUSION}

The result of the study, which are underlie on the extended TAM model, increases the understanding of the antecedents of MAS acceptance to adopt and how the leadership moderates the relationships between PNGAs' beliefs and their intention of MAS adoption, and offers some relevant implications and recommendations for future research. Through empirically investigating via responses to a survey of 419 PNGAs in Vinh Long province or other provinces or cities, the results reveal three major theoretical implications presented in turn.

Firstly, this study confirmed the findings of last researches in relation to the characteristics of MAS and provided extensive theoretical explanations for the argument that PNGAs may base their decision to adopt MAS in case their beliefs of the benefits and costing that can be gathered from this system. The final results of the current study suggest that PU, PEOU should be factors influencing and creating the impetus for future intentions of MAS adoption.

Secondly, contrasting with previous research, we add to the literature by exploring the effect of PFC as the factor influencing on the intention to MAS adoption. With the view that autonomy is an essential trend and preliminary condition development of economy and reduce the constrain of budget, all the PNGAs in the process of autonomy have to find a solution to enhance the management and control all the activities, especially the operating cost. For this reason, PNGAs tend to invest on new system with caution on the cost.

Thirdly, with regard to the moderating effects of leadership, SCs and DCs particularly, the relationship between PEOU, PE and ITA is more sensitive among the PNGAs which own the leadership with high strategic and dynamic capabilities than among the PNGAs which owns the lower ones. In contrast, the moderating effects of strategic and dynamic capabilities can have negative influence on the relationship between PFC and ITA. In other word, in comparison with high strategic and dynamic capabilities, the leaders with lower strategic and dynamic capabilities tend to refuse to apply MAS in case the cost is supposed to be so high.

This study also offers some important managerial implications for how to increase the intention to adopt MAS among PNGA, particularly for PNGA in Vinh Long. Firstly, the leader should take a lead in exploring new approaches to closing the skills gap among the employees through eliminating barriers for learning to apply new system and improve the speed of searching for new knowledge by training and education. Secondly, managers must identify

the change speed of technology and pay attention to increase the management knowledge and practices.

Concretely speaking, MAS providers might use the leadership as the criterion for segmenting the market to satisfy the needs of various groups of consumers, they may provide high leadership (high strategic and dynamic capabilities) with more useful and more tailored services for MAS to give assistance and find solutions to making effective decision and enhance the management performance and to facilitate more low leadership (high strategic and dynamic capabilities) to get the suitable and economic cost access. This study also suggests that MAS providers should endeavor to minimize the price of MAS, and offer a straightforward way to deliver benefits and easy to use to boost PNGAs' adoption intention of MAS.

Apart from contributing to such knowledge, this research still suffered from a few of limitations that provide chances for further research. First, because the data of this research were collected from accountants working in the public education sectors and public hospitals only, given this study's limited scope, further research may generalize this study's sample to the respondents of different position or field of the organization. Secondly, there were some regions in the sample failing the meet the standard of quantity, hence this problem should be addressed by future researchers. Thirdly, there is still claimed for replicated research to achieve a better understanding the patterns of the existence of the moderating effects through another procedure, although MGA can be used to in this research model, the methods could not allow for a plotting of the moderation relationships. Fourthly, based on the cross-sectional research method, the relation between intention and actual use are still questions, therefore, longitudinal analysis by taking into consideration the evolution of MAS acceptance over time should be applied by future researchers.

\section{REFERENCES}

1. Agarwal, R., \& Prasad, J. (1999). Are Individual Differences Germane to the Acceptance of New Information Technologies? Decision Sciences, 30(2), 361-391. doi:10.1111/j.1540-5915.1999.tb01614.x.

2. Agbejule, A. (2005). The relationship between management accounting systems and perceived environmental uncertainty on managerial performance: a research note. Accounting and Business Research, 35(4), 295-305. doi:10.1080/00014788.2005.9729996.

3. Al-Omiri, M., \& Drury, C. (2007). A survey of factors influencing the choice of product costing systems in UK organizations. Management Accounting Research, 18(4), 399-424. doi:10.1016/j.mar.2007.02.002.

4. Alsajjan, B., \& Dennis, C. (2010). Internet banking acceptance model: Cross-market examination. Journal of Business Research, 63(9-10), 957-963. doi:10.1016/j.jbusres.2008.12.014.

5. Anderson, J.C., \& Gerbing, D.W. (1988). Structural equation modeling in practice: a review and recommended two-step approach. Psychological Bulletin, 103(3), 411-423. doi:10.1037/0033-2909.103.3.411.

6. Anh, D. N. P. (2016). Factors Affecting the Use and Consequences of Management Accounting Practices in A Transitional Economy: The Case of Vietnam. Journal of Economics and Development, 18(1), 54-73.

7. Arbuckle, J.L. (2003). AMOS 5.0: Update to the AMOS User's Guide. Smallwaters Corporation, Chicago, IL.

8. Bagozzi, R. P., \& Yi, Y. (1988). On the evaluation of structural equation models. Journal of the Academy of Marketing Science, 16(1), 74-94. doi:10.1007/bf02723327. 
9. Baines, A., \& Langfield-Smith, K. (2003). Antecedents to management accounting change: a structural equation approach. Accounting, Organizations and Society, 28(1), 675-698.

10. Bhattacherjee, A. (2001a). Understanding Information Systems Continuance: An Expectation-Confirmation Model. MIS Quarterly, 25(3), 351. doi:10.2307/3250921.

11. Bhattacherjee, A. (2001b). An empirical analysis of the antecedents of electronic commerce service continuance. Decision Support Systems, 32(2), 201-214. doi:10.1016/s0167-9236(01)00111-7.

12. Bhattacherjee, A., \& Premkumar, G. (2004). Understanding changes in belief and attitude toward information technology usage: a theoretical model and longitudinal test. MIS Quarterly, 28(2), 351-370.

13. Bollen, K. A. (1989). A New Incremental Fit Index for General Structural Equation Models. Sociological Methods and Research, 17, 303-316. https://doi.org/10.1177\%2F0049124189017003004.

14. Bouwens, J., \& Abernethy, M. A. (2000). The consequences of customization on management accounting system design. Accounting, Organizations and Society, 25(3), 221-241. doi:10.1016/s0361-3682(99)00043-4. learning. Journal of Research in Innovative Teaching \& Learning. doi:10.1108/jrit-03-2017-0004.

16. Byrne, B.M. (2001). Structural Equation Modeling with AMOS: Basic Concepts, Applications, and Programming. Lawrence Erlbaum Associates, Mahwah, NJ.

17. Çelik, H. (2008). What determines Turkish customers' acceptance of internet banking? International Journal of Bank Marketing, 26(5), 353-370. doi:10.1108/02652320810894406.

18. Cheng, M. (2012). The joint effect of budgetary participation and broad-scope management accounting systems on management performance. Asian Review of Accounting, 20(3), 184-197. doi:10.1108/13217341211263256.

19. Chenhall, R. H. (2003). Management control systems design within its organizational context: findings from contingency-based research and directions for the future. Accounting, Organizations and Society, 28(2-3), 127-168. doi:10.1016/s0361-3682(01)00027-7. strategic priorities, management techniques and management accounting: an empirical investigation using a systems approach. Accounting, $\begin{array}{lll}\text { Organizations and } & \text { Society, 243-264. }\end{array}$ doi:10.1016/s0361-3682(97)00024-x.

21. Chenhall, R.H., \& Morris, D. (1986). The impact of structure, environment, and interdependence on the perceived usefulness of management accounting system. The Accounting Review, 61(1), 16-35.

22. Chin, W. W., \& Gopal, A. (1995). Adoption intention in GSS: Relative importance of beliefs. ACM SigMIS Database, 26(2-3), $42-64$.

23. Chiou, J.-S., \& Shen, C.-C. (2012). The antecedents of online financial service adoption: the impact of physical banking services on Internet banking acceptance. Behaviour \& Information Technology, 31(9), 859-871. doi:10.1080/0144929x.2010.549509.

24. Chung, S.-H., Su, Y.-F., \& Yu-Ju, S. (2012). Broad scope management accounting system and managerial performance: the impact of role ambiguity and functional difference. African Journal of Business Management, 6(30), 8873-8878. https://doi.org/10.5897/AJBM11.2181

25. Davis, F. D. (1989). Perceived Usefulness, Perceived Ease of Use, and User Acceptance of Information Technology. MIS Quarterly, 13(3), 319. doi: $10.2307 / 249008$

26. Davis, F. D. (1993). User acceptance of information technology: system characteristics, user perceptions and behavioral impacts. International Journal of Man-Machine Studies, 38(3), 475-487. doi:10.1006/imms.1993.1022.

27. Davis, F. D., Bagozzi, R. P., \& Warshaw, P. R. (1989). User Acceptance of Computer Technology: A Comparison of Two Theoretical Models. Management Science, 35(8), 982-1003. doi:10.1287/mnsc.35.8.982.

28. Eisenhardt, K. M., \& Martin, J. A. (2000). Dynamic capabilities: what are they? Strategic Management Journal, 21(10-11), 1105-1121. doi:10.1002/1097-0266(200010/11)21:10/11<1105:aid-smj133>3.0.co; 2-e.

29. Etemadi, H., Dilami, Z.D., Bazaz, M.S., \& Parameswaran, R. (2009). Culture, management accounting and managerial performance: focus Iran. Advances in Accounting, 25(2), 216-225.

30. Fabrigar, L.R., Petty, R.E., Smith, S.M., \& Crites, S.L., Jr. (2006). Understanding knowledge effects on attitude-behavior consistency: the role of relevance, complexity, and amount of knowledge. Journal of Personality and Social Psychology, 90(4), 556-577.
15. Buabeng-Andoh, C. (2018). Predicting students' intention to adopt mobile

20. Chenhall, R., \& Langfield-Smith, K. (1998). The relationship between

31. Fornell, C., \& Larcker, D. F. (1981). Evaluating Structural Equation Models with Unobservable Variables and Measurement Error. Journal of Marketing Research, 18(1), 39. doi:10.2307/3151312.

32. Gao, L., \& Bai, X. (2014). A unified perspective on the factors influencing consumer acceptance of internet of things technology. Asia Pacific Journal of Marketing and Logistics, 26(2), 211-231. doi:10.1108/apjml-06-2013-0061.

33. Granlund, M. (2011). Extending AIS research to management accounting and control issues: A research note. International Journal of Accounting Information Systems, 12(1), 3-19. doi:10.1016/j.accinf.2010.11.001.

34. Hair, J.F., Anderson, R.E., Tatham, R.L., \& Black, W.C. (1998) Multivariate Data Analysis with Readings, (5 ${ }^{\text {th }}$ ed.). Prentice-Hall, Englewood Cliffs, NJ.

35. Hair, J.F., Black, W.C., Babin, B.J., \& Anderson, R.E. (2010) Multivariate Data Analysis: A Global Perspective, ( $7^{\text {th }}$ ed.). Pearson, Upper Saddle River, NJ.

36. Haiza Muhammad Zawawi, N., \& Hoque, Z. (2010). Research in management accounting innovations. Qualitative Research in Accounting \& Management, 7(4), 505-568. doi:10.1108/11766091011094554.

37. Halbouni, S. S., \& Nour, M. A. (2014). An empirical study of the drivers of management accounting innovation: a UAE perspective. International Journal of Managerial and Financial Accounting, 6(1), 60. doi:10.1504/ijmfa.2014.060512.

38. Hammad, S.A., Jusoh, R., \& Ghozali, I. (2010). Decentralization, perceived environmental uncertainty, managerial performance and management accounting system information in Egyptian hospitals. International Journal of Accounting and Information Management, 21(4), 314-330.

39. Harrell, J. F. (2015). Regression modeling strategies: With applications to linear models, logistic and ordinal regression, and survival analysis, (2nd ed.). Berlin, Germany: Springer International Publishing.

40. Helden, J., \& Uddin, S. (2016). Public sector management accounting in emerging economies: a literature review. Critical Perspectives on Accounting, 41(1), 34-62.

41. Hoelter, J. W. (1983). The Analysis of Covariance Structures. Sociological Methods \& Research, 11(3), 325-344. doi:10.1177/0049124183011003003.

42. Holmes-Smith, P., 2001. Introduction to Structural Equation Modelling using LISREL. Perth, ACSPRI-Winter training program.

43. Hoque, Z. (2011). The relations among competition, delegation, management accounting systems change and performance: a path model. Advances in Accounting, 27(2), 266-277.

44. Hubbard, G., \& Beamish, P. (2011). Strategic Management: Thinking Analysis \& Action, ( $4^{\text {th }}$ ed.). Sydney: Pearson Prentice Hall.

45. Ismail, K., \& Isa, C.R. (2011). The role of management accounting systems in advanced manufacturing environment. Australian Journal of Basic and Applied Sciences, 5(9), 2196-2209.

46. Ismail, N.A., \& King, M. (2007). Factors influencing the alignment of accounting information systems in small and medium sized Malaysian manufacturing firms. Journal of Information Systems and Small Business, 1(1-2), 1-20.

47. Karahanna, E., \& Limayem, M. (2000). E-Mail and V-Mail Usage: Generalizing Across Technologies. Journal of Organizational Computing and Electronic Commerce, 10(1), 49-66. doi:10.1207/s15327744joce100103.

48. Kline, R. B. (2011). Principles and practice of structural equation modeling, (3rd ed.). New York, USA: The Guilford Press.

49. Kwon, O., \& Wen, Y. (2010). An empirical study of the factors affecting social network service use. Computers in Human Behavior, 26(2), 254-263.

50. Lee, S. J. (2009). Online Communication and Adolescent Social Ties: Who benefits more from Internet use? Journal of Computer-Mediated Communication, 14(3), doi:10.1111/j.1083-6101.2009.01451.x

51. Lee, S. K. V. (2000). The Demand for Business and Management Education in Hong Kong Beyond 1997. in Rowley, C., Fitzgerald, R. (Eds), Managed in Hong Kong: Adaptive Systems, Entrepreneurship and Human Resource, Frank Cass, London.

52. Legris, P., Ingham, J., \& Collerette, P. (2003). Why do people use information technology? A critical review of the technology acceptance model. Information \& Management, 40(3), 191-204. doi:10.1016/s0378-7206(01)00143-4. 
53. Lei, P.-W., \& Wu, Q. (2007). Introduction to Structural Equation Modeling: Issues and Practical Considerations. Educational Measurement: Issues and Practice, 26(3), 33-43. doi:10.1111/j.1745-3992.2007.00099.x

54. Leite, A. A., Fernandes, P. O., \& Leite, J. M. (2015). Contingent factors that influence the use of management accounting practices in the Portuguese textile and clothing sector. The International Journal of Management Science and Information Technology, Special Issue: 2015 Spanish-Portuguese Scientific Management Conference (59 - 78).

55. Lenz, R.T. (1980). Strategic capability: a concept and framework for analysis. Academy of Management Review, 5(2), 225-334. doi 10.5465/amr.1980.4288736.

56. Luarn, P., \& Lin, H.-H. (2005). Toward an understanding of the behavioral intention to use mobile banking. Computers in Human Behavior, 21(6), 873-891. doi:10.1016/j.chb.2004.03.003

57. Mat, T.Z.T., Smith, M., \& Djajadikerta, H. (2010). Management accounting and organizational change: an exploratory study in Malaysian manufacturing firms. Journal of Applied Management Accounting Research, 8(2), 51-82

58. Mcmanus, L. (2013). Customer Accounting and Marketing Performance Measures in the Hotel Industry: Evidence from Australia. International Journal of Hospitality Management, 33(1), 140-152. https://doi.org/10.1016/j.ijhm.2012.07.007

59. Mia, L., \& Patiar, A. (2001). The use of management accounting systems in hotels: an exploratory study. International Journal of Hospitality Management, 20(2), 111-128. doi:10.1016/s0278-4319(00)00033-5

60. Mia, L., \& Winata, L. (2008). Manufacturing strategy, broad scope MAS information and information and communication technology. The British Accounting Review, 40(2), 182-192. doi:10.1016/j.bar.2008.02.003

61. Moffat, P., \& Simon, A. (2011). Strategic management capabilities that drive West Australian law firm success. Academy of Taiwan Business Management Review, 7(1), 1-12.

62. Moores, K., \& Yuen, S. (2001). Management accounting systems and organizational configuration: a life-cycle perspective. Accounting, Organizations and Society, 26(4-5), 351-389. doi:10.1016/s0361-3682(00)00040-4

63. Muthen, B., \& Kaplan, D. (1985). A comparison of some methodologies for the factor analysis of non-normal Likert variables: A note on the size of the model. The British Journal of Mathematical and Statistical Psychology, 45, 19-30.

64. Nunnally, J. C. (1978). Psychometric theory, (2 ${ }^{\text {nd }}$ ed.). New York: McGraw-Hill.

65. Preacher, K. J., \& Hayes, A. F. (2008). Asymptotic and resampling strategies for assessing and comparing indirect effects in multiple mediator models. Behavior Research Methods, 40(3), 879-891. doi: $10.3758 / \mathrm{brm} .40 .3 .879$

66. Santos, L.L, Gome, C., Arroteia., N., \& Almeida. P. (2012). The perception of management accounting in the Portuguese lodging industry. Global Business and Technology Association, GBATA 16th Annual International Conference, At Baku, Azerbaijan. doi: $10.13140 / 2.1 .2631 .3282$

67. Sarasvathy, S.D., \& Dew, N. (2013). Without judgement: an empirically based entrepreneurial theory of the firm. Review of Austrian Economics, 26(3), 277-296.

68. Simon, A. (2010). Resources, dynamic capabilities and Australian business success. Journal of Global Business and Technology, 6(2), 12-31.

69. Simon, A., Bartle, C., Stockport, G., Smith, B., Klobas, J. E., \& Sohal, A. (2015). Business leaders' views on the importance of strategic and dynamic capabilities for successful financial and non-financial business performance. International Journal of Productivity and Performance Management, 64(7), 908-931. doi:10.1108/ijppm-05-2014-0078.

70. Singh, J. (1995). Measurement Issues in Cross-National Research. Journal of International Business Studies, 26(3), 597-619. doi:10.1057/palgrave.jibs.8490188.

71. Sivo, S.A., Fan, X.T., Witta, E.L., \& Willse, J.T. (2006). The search for 'optimal' cutoff properties: fit index criteria in structural equation modeling. The Journal of Experimental Education, 74(3), 267-288. https://psycnet.apa.org/doi/10.3200/JEXE.74.3.267-288.

72. Soobaroyen, T., \& Poorundersing, B. (2008). The effectiveness of management accounting systems. Managerial Auditing Journal, 23(2), 187-219. doi:10.1108/02686900810839866.

73. Sripalawat, J., Thongmak, A., \& Ngramyarn A. (2011). M-banking in Metropolitan Bangkok and a Comparison with Other Countries. Journal of Computer Information Systems, 51(3), 67-76. doi: 10.1080/08874417.2011.11645487.
74. Suoranta, M., \& Mattila, M. (2004). Mobile Banking and Consumer Behaviour: New Insights into the Diffusion Pattern. Journal of Financial Services Marketing, 8(4), 354-366. doi:10.1057/palgrave.fsm.4770132.

75. Urquidi, A.C., \& Ripoll, V.M. (2013). The choice of management accounting techniques in the hotel sector: the role of contextual factors. Journal of Management Research, 5(2), 65-82.

76. Van Helden, J., \& Uddin, S. (2016). Public sector management accounting in emerging economies: A literature review. Critical Perspectives on Accounting, 41, 34-62. doi:10.1016/j.cpa.2016.01.001.

77. Venkatesh, Morris, Davis, \& Davis. (2003). User Acceptance of Information Technology: Toward a Unified View. MIS Quarterly, 27(3), 425. doi: $10.2307 / 30036540$.

78. Venkatesh, V., \& Morris, M.G. (2000). Why Don't Men Ever Stop to Aask for Directions? Gender, Social Influence, and Their Role in Technology Acceptance and Usage Behavior. MIS Quarterly, 24(1), 115-139. doi: $10.2307 / 3250981$

79. von Krogh, G., Nonaka, I., \& Aben, M. (2001). Making the most of your company's knowledge: a strategic framework. Long Range Planning, 34(4), 421-439.

80. Wallace, L. G., \& Sheetz, S. D. (2014). The adoption of software measures: A technology acceptance model (TAM) perspective. Information \& Management, 51(2), 249-259. doi:10.1016/j.im.2013.12.003.

81. Wu, J.-H., Wang, S.-C., \& Lin, L.-M. (2007). Mobile computing acceptance factors in the healthcare industry: A structural equation model International Journal of Medical Informatics, 76(1), 66-77. doi:10.1016/j.ijmedinf.2006.06.006.

82. Yang, H., Liu, H., \& Zhou, L. (2012). Predicting young Chinese consumers' mobile viral attitudes, intents and behavior. Asia Pacific Journal of Marketing and Logistics, 24(1), 59-77. doi:10.1108/13555851211192704.

83. Yang, K.C.C. (2005). Exploring Factors Affecting the Adoption of Mobile Commerce in Singapore. Telematics and Informatics, 22(3), 257-277. doi:10.1016/j.tele.2004.11.003.

84. Zaleha Abdul Rasid, S., Rahim Abdul Rahman, A., \& Khairuzzaman Wan Ismail, W. (2011). Management accounting and risk management in Malaysian financial institutions. Managerial Auditing Journal, 26(7), 566-585. doi:10.1108/02686901111151314.

85. Zhu, K., Kraemer, K. L., \& Dedrick, J. (2004). Information Technology Payoff in E-Business Environments: An International Perspective on Value Creation of E-Business in the Financial Services Industry. Journal of Management Information Systems, 21(1), 17-54. doi:10.1080/07421222.2004.11045797.

86. Zikmund, W.G., Babin, B.J., Carr, J.C., \& Griffin, M. (2010). Business Research Methods, $\left(8^{\text {th }}\right.$ ed.). Cengage Learning, Mason, HO 